\title{
A. Gabriel Meléndez, The Book of Archives and Other Stories from the Mora Valley, New Mexico, Norman, University of Oklahoma Press, 2017, 232 pp.
}

No es la primera vez que el Gabriel Meléndez de la Universidad de Nuevo México (Alburquerque, EE. UU.) publica leyendas nuevomexicanas en edición bilingüe, pues en 2013 publicó The Legend of Ponciano Gutiérrez and the Mountain Thieves, una hermosa historia de aventuras conservada en la memoria de la familia Paiz hasta que él la recogió y la editó ilustrada para niños (y adultos). Las dos obras relatan fábulas contadas en el Valle de Mora, del que Meléndez es nativo. El valle está resguardado en la Sierra de la Sangre de Cristo perteneciente a las Montañas Rocosas en la parte más meridional y, dicho sea de paso, destacamos lo respetuosos que son los norteamericanos con la toponimia española.

Esta publicación y la que ahora reseñamos encajan perfectamente en los intereses y la trayectoria académica del autor centrada en la crítica literaria, la crítica cinematográfica y la etnohistoria americana, especialmente en los territorios que fueron españoles desde 1598, después del fracaso de otras expediciones, y mexicanos con la independencia desde 1821. También ha trabajado con profusión las historias de vida y el imaginario étnico y cultural del Sudoeste de los Estados Unidos. En todo este acervo que mezcla tradición y memoria tiene cabida El libro de los Archivos.

El libro es una colección de cuarenta y dos relatos de extensión dispar y muchos relacionados entre ellos, que es reelaborada por el autor cuando la escribe sin que el interés mengüe a medida que avanza. La génesis de la colección es otra historia tan sorprendente como algunas de la propia recopilación y que se narra en dos relatos «El libro de los archivos» $\mathrm{y}$ «Mora es bombardeada», aunque hay otros que tienen que ver con su desenlace que se evoca sin tregua. Cuenta la leyenda que Meléndez inventa que los habitantes del Valle de Mora documentan desde un tiempo impreciso, lejano y anterior a la llegada de los colonos de los Estados Unidos su memoria e identidad en un libro de cuero atado con correas en el que almacenan materiales heterogéneos: poesía, artículos de periódicos, registros, crónicas, bosquejos histórico-geográficos... El libro comenzaba con la frase «En el principio del mundo...» dando a entender que el mundo había comenzado allí, en el mismo lugar donde se custodiaba dicho manuscrito. Pero cuando estalla la guerra entre México y Estados Unidos (1848-1846) los americanos anexionaron varios territorios, entre ellos Nuevo México, y una bomba causó el desastre destrozando el libro de la memoria y a sus dos últimos custodios, los ancianos Agustín y Tacha Valdez:

el estallido del proyectil les rompió los tímpanos de los oídos y luego les quemó las retinas de los ojos con el deslumbre de una explosión que les quemó las carnes, abriendo un hueco en la tierra en el mero lugar donde Agustín Valdez había hecho enterrar con tanto cuidado su sagrado Libro de Archivos. [...] Entre el humo y los escombros volaban también las hojas desgarradas y chamuscadas del libro de Agustín Valdez, asidas por un viento que tiraba al sur y yendo a desparramarse por lo largo y ancho del valle como las hojas de los álamos que caen al suelo (130). 
Después de la guerra Meléndez narra como la historia del lugar se trasmite oralmente de generación en generación dentro de las familias y pueblos, el relato pertenece a todos, a la comunidad entera.

Hay un hilo conductor que pasa por todos los relatos, el cambio cultural, a pesar de que el primitivo libro de archivos y el que se reelabora ahora sean, cada uno a su manera, ejercicios de resistencia cultural. Este cambio lo sufren los indios - navajos, indios pueblo y apaches - , los colonos mexicanos y los colonos y militares yanquis, que conociendo el valle por primera vez «eran como hombres ciegos», y otros europeos como el sacerdote francés P. Avel o el alemán Pablo Steiner, pero sobre todos ellos pesa otra categoría étnica que se impone en todas las historias, la de mestizo como en el relato «Sarita, la genízara». La mudanza se asocia un progreso que hace que la gente «no era la misma de antes», pues, aunque todavía se vivía en función de la tierra y las tradiciones, dejan de interesar las historias de los trovadores en favor de las promesas de los políticos, las mercancías y los oficiales federales que recordaban que eran tutelados por Estados Unidos. Pero a pesar de las maniobras de Waldo Catrine y sus secuaces - personajes que asemejan a los especuladores de terrenos que después emigraran a Nuevo México- han pervivido hasta hoy usos y leyendas vernáculas en la lengua de Garcilaso de la Vega. No importa que los otros no entiendan nada de «la más miserable y rústica gente sobre la tierra», que no sepan que vender el rancho es como vender la madre, pues sus cuentos refuerzan su idiosincrasia y su libro mítico el origen del mismo mundo. Aunque los símbolos del progreso sean otros bien distintos - locomotoras, periódicos bilingües, etc. — todavía hoy se celebra la Pasión del Señor en las Moradas de los penitentes y la Pascua de Resurrección, se saca a los santos por la Cruz de mayo, se le piden imposibles a San Antonio... y se interpretan los sueños.

También la muerte se personificada como una escultura en madera conocida popularmente como la comadre Sebastiana, aunque tiene muchos nombres en la visión que relata Meléndez, sigue sentada en su trono, una carreta, su rostro está cubierto con un rebozo y porta un arco y una flecha para recordarle a todos que un día ricos y pobres, guapos y feos, listos y tontos, indios, mexicanos y americanos han de subir a su carro. De esta manera la Sebastiana es protagonista de muchas historias de Mora: difuntos como Petra que se aparecen para despedirse de su amor verdadero, el jinete cazador de cíbolos (bisontes americanos) que con mala suerte muere, una viva a la que se le da sepultura como muerta y los espíritus de los indios que están enterrados en todos los lados.

La guerra se presenta como verdad dolorosa y probada que ha llevado la ocupación y ha hecho que la soberbia se enseñoree de todo. El General Carne, nombre que Meléndez inventa para el comandante norteamericano que conquistó Nuevo México, no se satisface con vencer, además humilla a los habitantes que considera «incorregibles mestizos». Pero hay otras verdades tan dolorosas como convincentes como la esclavitud y los robos de mujeres y niños. El cautiverio de los indios y nuevomexicanos que dura varias generaciones se representa como el caso de la india comanche Sara y su desdichada hijita dando a conocer una historia cruel. El comienzo del siglo veinte no trae ventura, sino sequía, hambre, emigración forzosa del campo a la ciudad y desarraigo. A los nuevomexicanos se les recluta como soldados nuevos-yanquis para la guerra europea, etc. Las guerras del futuro serán igual de espantosas, hay seres queridos enterrados en la lejana Normandía y otros como «Pite Chotas» que pierde un pie en Corea, pero también ha perdido su alma.

Meléndez va recomponiendo la historia de la memoria con personajes populares — brujas y hechiceros, curanderas («médicas»), la alcahueta restauradora de hímenes, 
Mana Romancita, un abuelo desconfiado, estupefacto e incrédulo ante los nuevos inventos-; animales — cíbolos, osos, caballos y perros que huelen la muerte o no-; una beldad, Julia Pacheco, y su pléyade de pretendientes; el prohombre Eusebio Romero, humilde, que entendió que «su primera y verdadera educación le había llegado de su gente», déspotas ajenos y, con amargura, también caciques cercanos; gente honrada y trabajadora, chismosos y un vago redomado; una monja de Ágreda, «La dama azul», que en el s. XVII tenía el don de la bilocación y grandes dotes para convertir indios; y por supuesto los poetas populares, uno además bufón de virrey.

Mediante la narración podemos interpretar los valores instaurados en el pensamiento de los aldeanos de Valle que obligan, por ejemplo, a que «ningún pecador, por más ignoble, se vaya del mundo sin una despedida formal» (203) o que en una Morada los hermanos de una cofradía rezan una petición por cada alma en el tiempo santo (p. 230). Si el mito es algo viviente porque, como afirmó Mircea Eliade es la base de la vida religiosa, el que teje este libro, asumiendo toda su ficción, parte de un poso de verdad. Por fortuna A. Gabriel Meléndez continua la tarea de sus antepasados y ha registrado los cuentos del Valle de Mora para que nosotros podamos disfrutarlos: ¿Será una aparición sorprendente de los trovadores errantes y rivales Viejo Vilmas y Negropoeta García para recitar sus corridos, décimas y memorias?

M. ${ }^{\text {a }}$ Pilar Panero García

(Universidad de Valladolid)

$$
\text { j }
$$

